\title{
601865
}

2. T0: (Recolving Organization)

ETr Procese Engineering

5. Proj/Prog JDept/Div.:

Weste Managemont Hanford

8. Originator Remarks:

The attached denign analysis supports pH monitor installation on the ETI evaporator akid (ref:ECN-651583). Thin annlyeis provides orifice sizing onloulation to assure appropriate flow through the pli monitor.

11. Receiver Remarks: 11A. Design Baseline Documant? O Yas O No $\mathbf{n} / \mathbf{a}$
3. From: (Orginating Organization)

scott D. Ellingson EDH

6. Design Authorty/Design Acent/Cog. Engr::

D.t. Scally/s.D. Ellingson
4. Related EDT No.:

$\mathbf{n} / \mathbf{a}$

7. Purchase Order No.:

$\mathbf{n} / \mathbf{a}$

9. Equip./Component No.:

$\mathbf{n} / \mathbf{a}$

10. Syatem/Bldg./Faclity:

2025:

12. Major Aeern. Dwg. No.:

$\mathrm{n} / \mathbf{a}$

13. PermitPermit Application No.:

$\mathbf{n} / \mathbf{a}$

14. Required Respones Date:

n/a

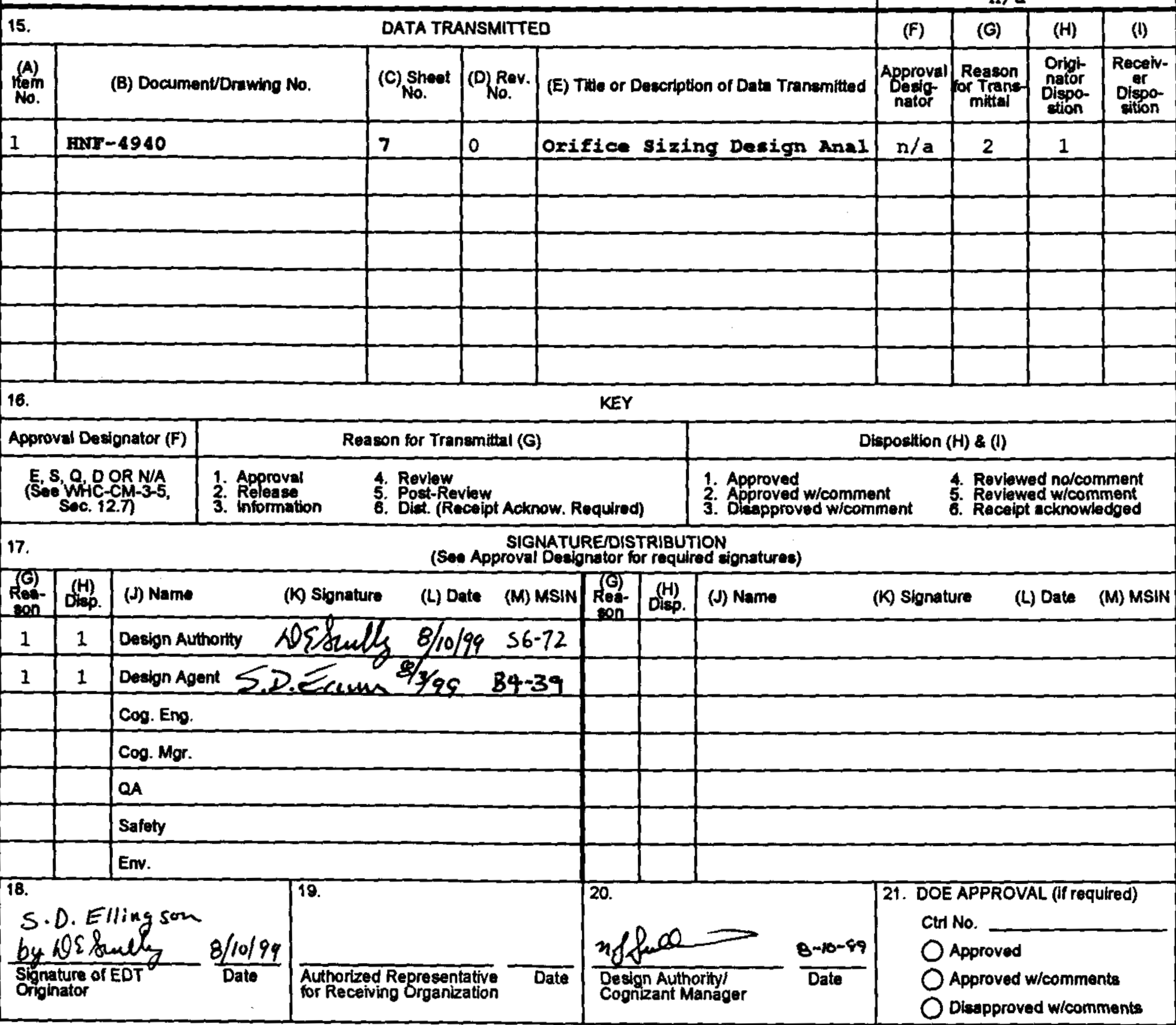

BD-7400-172-2 (10/97) 


\section{ETF Facility Evaporator Skid Orifice Sizing Design Analysis}

8.D. Hlingeon for

Waste Management Hanford

Richland, WA 99352

U.S. Department of Energy Contract DE-AC06-96RL13200

EDT/ECN: 601865

UC: 502

Org Code: R3111200

B\&R Code: EW3130020

Charge Code: 101697

Total Pages: 7

Key Words: Effluent Treatment Facility, ETF, 2025E, Orifice, Evaporator

Abstract:

This document releases and records the design analysis for sizing the orifice plate being installed on the ETF evaporator skid per Encineering Change Notice (ECN) 651583.

TRADEMARK DISCLAIMER. Reference herein to any specific commercial product, process, or service by trade name, trademark, manufacturer, or othenwise, does not necescarily constitute or imply ths endoreement, recommendation, or fevoring by the United States Covernment or any agency thereof or its contractors or subcontractors.

Printed in the United States of America. To obtain copies of this document, contact: Document Control Services, P.O. Box 950, Mailstop H6-08, Richland WA 99352, Phone (509) 372-2420; Fax (509) 376-4989.
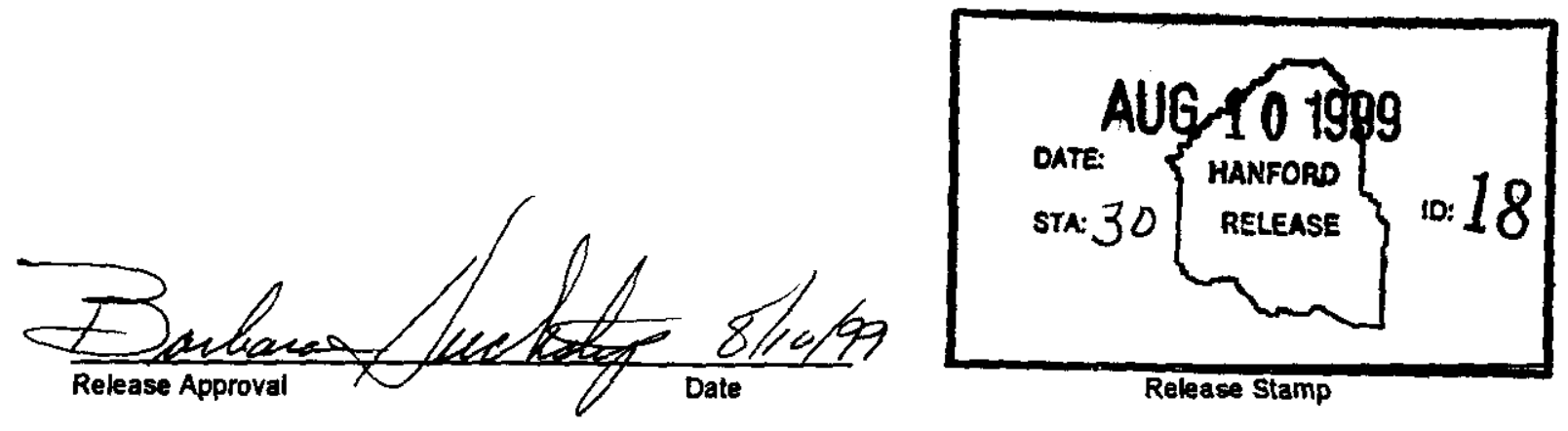

\section{Approved For Public Release}


HNF-4940, Rev 0, Page 1

FLUOR DANIEL NORTHWEST

CALCULATION IDENTIFICATION AND INDEX

Calc. No. 191-15-M-(3)

TO Joh No. Contract 191. Release 15

Late: $7 / 16 / 99$

This sheet shows the status and description of the attached Calculation Sheets.

Disciplite: Mechanical

l'roject No. \& Title: Oritice Addition to the $2025 \mathrm{E}$ (F,TF) Evaproator Skid

Calculations: Orifice Sizing and Selection

These catculations apply to

\begin{tabular}{|c|c|c|}
\hline 1) rawing $\mathrm{No}$. & H-2-88987, Sheet I & Rev. No. \\
\hline 1) rawing No. & H-2-89) 83, Sheet 1 & Rev. No \\
\hline Other (Study; & (J) $\quad \mathrm{ECN}-651583$ & \\
\hline
\end{tabular}

Rev. No.

The status of these calculations is

(a) Ireliminary (atcalations

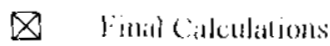

[ C Check Calcolations on calchitatrons dialed:

[] Void Cithulatoms (reisonl voided)

Were carculations incomporated into the linal drawingss?

区 Yes

[] No

Were catudations veritied by independen "clect" calculations?

$\square$ Yes

$\bigotimes \quad$ No

Original and Rovised Calculation Approvals

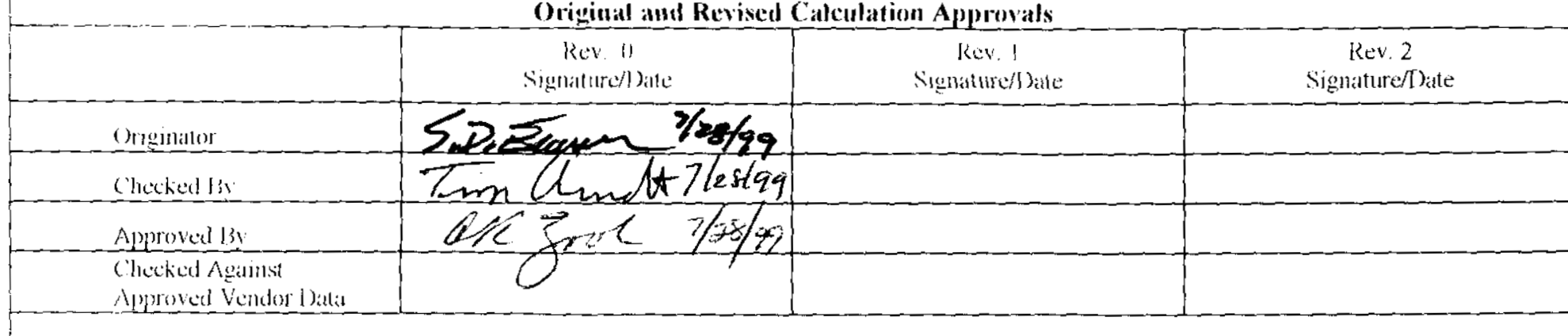

$|N|) \mid: X$

Cirletidtum Shet

lage No.

Description

$1-4$

Orifuct siang

Amx ly

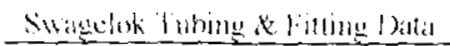


FLUOR DANIEL NORTHWEST, INC.

DESIGN ANALYSIS
Calc. No. $191-15-M-01$

Revision

Page No.

WO/Job No. Contranct 191 , RElleAsce 15

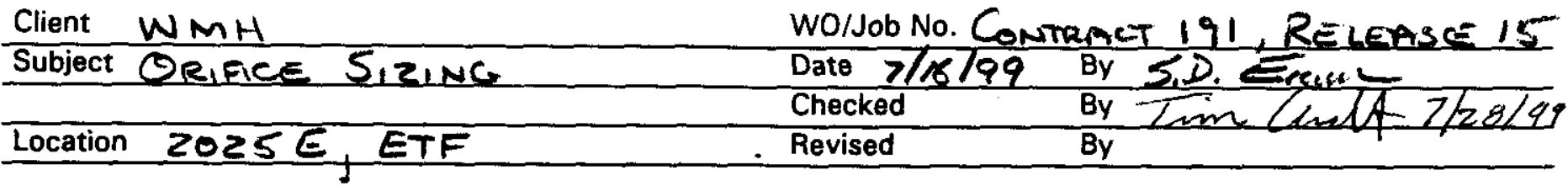

GIVEN THE PIPING SYSTOM SHOWN BELOW WITH THE GIVEN parameters. THE SYSTEM is flOWING WATER. Reference ECN- 651583

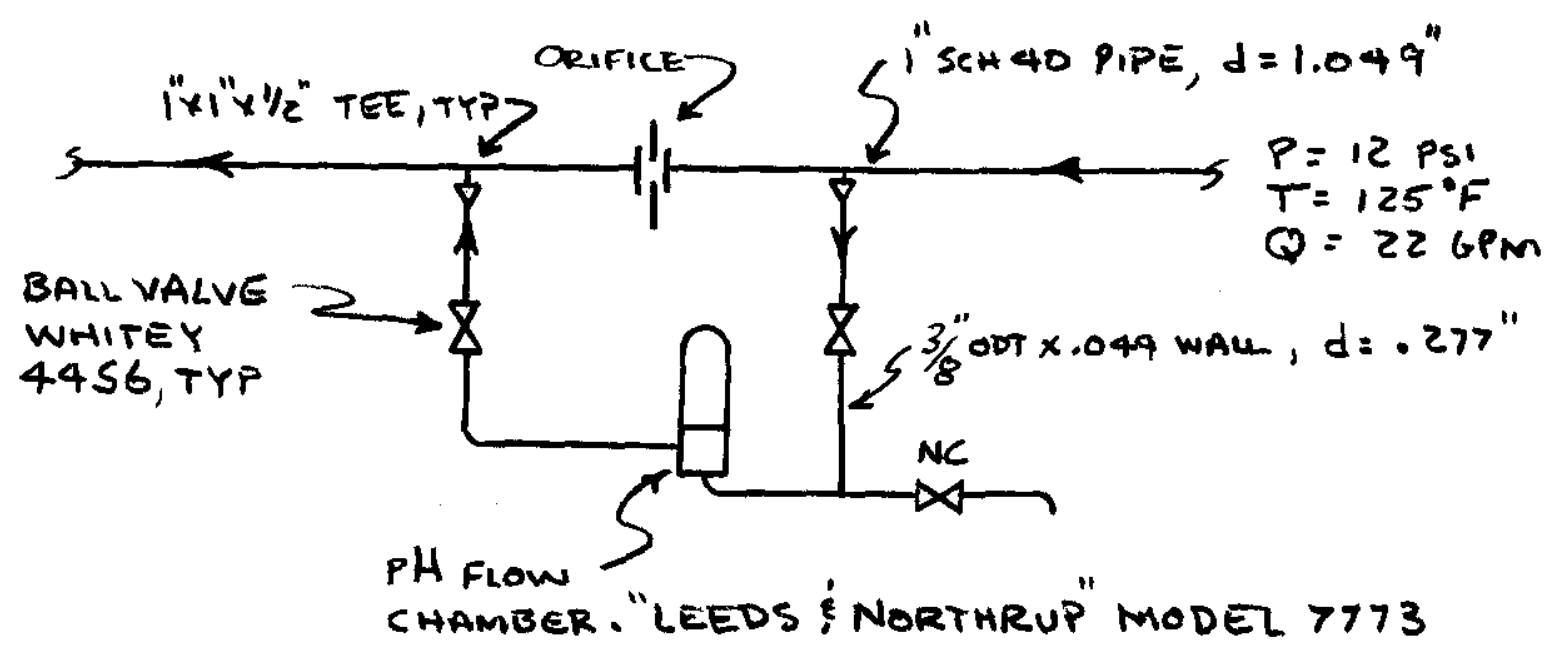

REQUIREO DETERMINE THE APPROPRIATE ORIFICE TO ASSUICE FLOW THROUGH THE PH METER. FLOW SHALL NOT EXCEED $15 \mathrm{GPM}$ THROUGH THE ORIFICE METER PER MANUFACTURERS REQUIRE MENTS.

SOLUTION THE FOLLONING STEPS MILL BE TAKEN TO CONCLUDE A SOLUTION.

(1) DETERMINE AN APPROPRIATE FLOWRATE THROUGH THE TUBING LOOP AWD PH METER

(C) DETERMINE THE PRESSURE DROP THROUQH THE TUBING LOOP SUCH THAT ORIFICE SIZE CAN BE DETERMINOSD. THE ORIFICE MUST PROVIDE THE NELESSARY BACK PRESSURE TO PRODUCE FlOW THROUGH THE TUBING LOOP.

(3) DETERMINE ORIFICE SIZE.

FOR SOLUTION RESULTS, SEE BOTTOM OF PAGE 4 
HNF-4940, Rev 0, Page 3

FLUOR DANIEL NORTHWEST, INC.

DESIGN ANALYSIS
Talc. No. $\frac{191-15-M-01}{0}$

Page No. 2 of 4

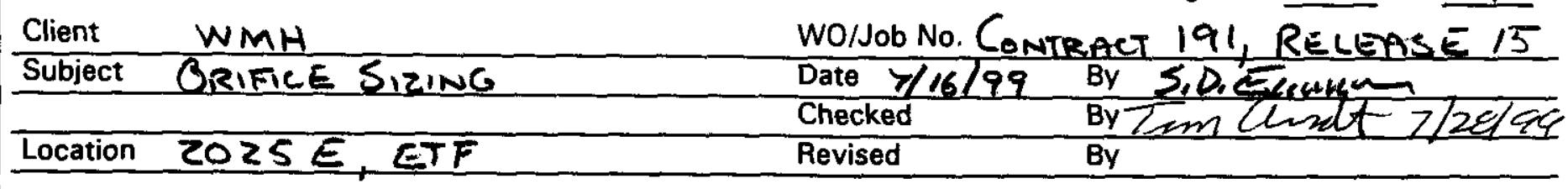

THE FOLLOWING REFERENCES WILL BE USED TO PROVIDE A CONCLUSION:

1. Crane Technical Paper No. $410,19^{\text {Th }}$ Printing, 1980

2. SWAGElOK tUBE FITtERS MANUAL, 1993 EDITION

3. SWAGELOK VENDOR CATALOL.

(1) Determine an appropriate flowrate through the tubing LOOP:

SINCE THE PH METER MAMUFACTURER haS No REQUIREMENT FOR MINIMUM FLOW, PICK A FLOWRATE BASED ON A REASONABLE STREAM VELOCITY, BUT NOT TO EXCEED 15 GP MI.

CHECK VELOCITY AT I GPA. FOR $3 / 8$ "X.049 TUBING;

$$
v_{T}=\frac{Q_{T}}{A_{T}}=\left(\frac{1 \text { GAL }}{\text { MIN }}\right)\left(\frac{\text { MIN }}{60 \text { SEC }}\right)\left(\frac{1 F^{3}}{7.481 G A L}\right)\left(\frac{4}{\pi}\right) \frac{144}{(.277)^{2}}=5.32 \mathrm{FT} / \mathrm{SEC}
$$

THIS IS A REASONABLE VELOCITy, AND THEREFORE FLOWRATE. USE I GPA THROUGH THE TUBAS LOOP.

(2) DETERMINE PRESSURE DROP THROUOH THE TUBING LOOP;

THE FOLLOWING COMPONENTS WILL PROVIDE LOSSES:

1. Total LENGTH OF $3 / 8$ " X.049 TUBING $=5 \mathrm{FT}$

2. DTY ( 2 ), "X IX $/ 2$ " REDUCING TEES, SCH 40

3. OYY CIS, 3/8" SWAGELOK TEE, BRANCh FLOW

4. QTY (2), 3/8, 90 TUBINE. BONDS

5. QTY $(Z)$, 3/8" WHITEY 4456 BALL VALVES

6. QTY (1), ENTRAMCE INTO THE PH METER FLOW CHAMBER

7. OIY (I), EXIT OUT OF THE PH METER FLOW CHAMBER

- the pressure drop for the tubing, tubinG bends, and s swaGeloir TEE CAN BE OBTANED FROM REFERENCE 2 , CHART 3 , WITH BENDS AND FITtINGS CONVERTED TO EQUIVALENT LENGTHS. SEE APPENDIX FOR REFERENCE.

$$
\text { TOTAL LENGTH }=\text { PIPE + BENDS + TEE }=5^{\prime}+(2) .5^{\prime}+1.5^{\prime}=7.5^{\prime}
$$

FROM CHART 3, $\triangle P / 100$ @ IGPM $\$ .099$ WALL $=26 \mathrm{PSI}$

$$
\therefore \quad \Delta P=\frac{7.5}{100}\left(26 P_{51}\right)=1.95 \mathrm{PS1}
$$

BD-6002-142 (12/96) 
HNF-4940, Rev 0, Page 4

FLUOR DANIEL NORTHWEST, INC.

DESIGN ANALYSIS
Call. No. $191-15-M-01$

Revision 0

Page No. 3 of 4

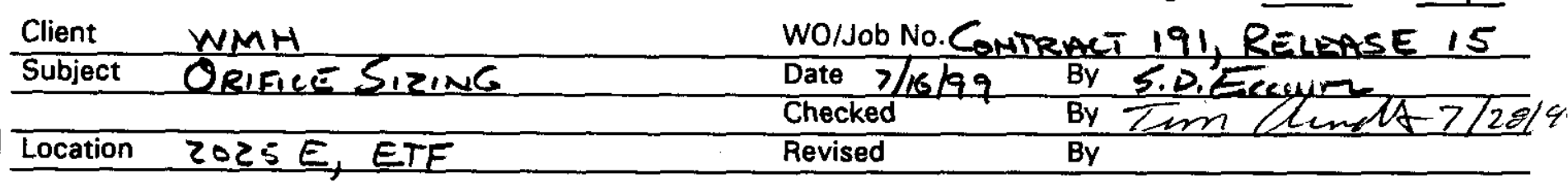

(2) CONTINUED

- Pressure drop for the whites ball valves will be determined FROM EQ 3.16 OF REF 1, USING A CV FACTOR FROM REF 3.

$$
\begin{aligned}
& \triangle P=\frac{Q^{2} P}{C_{\nu}^{2} 62.4} \text { WHERE } Q=Q_{T}=1 \mathrm{GPM} \\
& \rho=61.63 \mathrm{LBS} / R T^{3} \text {, WATER Q } 125^{\circ} \mathrm{F} \text {, PS A-6, REF I } \\
& C_{V}=6 \text { FOR WHiTEY BALL VALVES } 4456 \\
& \Delta P=\frac{(2)(1)^{2}(61.63)}{(6)^{2}(62.4)} \\
& \text { tONI FORGET TY ? } \\
& \Delta P=.05 \text { PSI }
\end{aligned}
$$

- pressure drop for the ixi"x y" reducing tee's will be assumes TD BE BRANCH FLOW FOR $1 / 2$ " TEES. USE ED 3-14 AND PAGE A-29 OF REF 1. ALSO ASSUME TURBULENT FLOW AMD $F=.027$

$$
\Delta P=1.078(10)^{-4} K \rho v^{2} \text { WHERE } K=(2) 60 f=(2)(60)(.027)=3.24
$$

FOR QTY 2

$P=61.63$ AS BEFORE

$N=5.32$ AS BEFORE

$$
\Delta P=1.078(10)^{-4}(3.24)(61.63)(5.32)^{2}=.61 \text { PS 1 }
$$

- pressure drop for the ph meter chamber entrance will be based on eQ 3-14 and page a-29 of ref 1 again

$\triangle P=1.078(10)^{4} K \rho v^{2}$ WHERE $K=.5$ PEi SAME AS BEFORE

$$
\Delta P=1.078(10)^{-4}(.5)(61.63)(5.32)^{2}=.09 \mathrm{PS1}
$$

- pressure drop for the ph meter exit will be similar WITH $K=1$

$$
\Delta P=1.078(10)^{-4}(1)(61.63)(5.32)^{2}=.19 P S 1 \leftarrow
$$

TOTAL $\triangle P=1.95+.05+.61+.09+.19=2.89$ PS 1

ROUND OFF TO 3 PSI

$B D-6002-142(12 / 96)$ 
HNF-4940, Rev 0, Page 5

FLUOR DANIEL NORTHWEST, INC.

DESIGN ANALYSIS
Calc. No. $191-15-M-01$

Revision

Page No. 4 of 4

Client WMH WO/Job No.Conmrnct 19!, RELEASE 15

Subject ORIFICE SizING Date $7 / 16 / 99$ By S. D-E

Location 2025E, ETF

Revised

By

(3) DETERMINE ORIFICE SIZE:

ORIFICE SIZE WILL BE DETERMINED USING EQ 3-2I AND PAGE A.ZO OF REF 1. THE APPROACH WILL BE TO ASSUBE A $B$ RATIO (di) AND THE COMPARE THE CALCULATED dI WITH THAT ASSUMED.

$$
\Phi=236 d_{1}^{2} c\left[\frac{\Delta P}{\rho}\right]^{1 / 2} \Rightarrow d_{1}=\left[\frac{Q}{(236)(c)\left[\frac{\Delta P}{P}\right]^{1 / 2}}\right]^{1 / 2}
$$

TO DETERMInE "C", MUST FIRST FIND Re BASE ON FLOW In dz, IE AT $Q=22-1=21$ G PM WITHIN I"SCH 40 PIPE. USE EQ $3-3$ OF REF 1.

$$
\begin{aligned}
& \operatorname{Re}=123.9 \frac{d z v P}{\mu} \quad \text { WHERE: } \begin{aligned}
d_{2} & =1.049^{\prime \prime} \\
\rho & =61.63^{\mathrm{LS}} / \mathrm{FT}^{3}
\end{aligned} \\
& \operatorname{Re}=(123.9)(1.049)(7.79)(61.63) \quad \mu=.52 \text { CP, PS Ar, REF }
\end{aligned}
$$

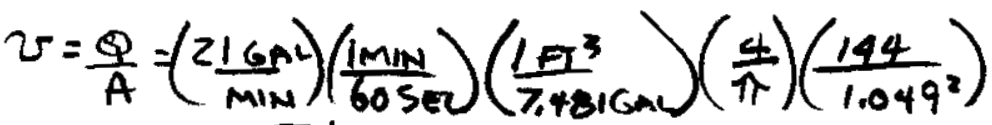

$$
\begin{aligned}
& R_{e}=1.2(10)^{5} \\
& v=7.79 \mathrm{FT} / \mathrm{SEC}
\end{aligned}
$$

AsSUME $\beta=.75 \Rightarrow d_{1}=\beta d_{2}=(.75)(1.049)=.78^{\prime \prime}$

FIND "C "From PS A.20@B=.75 $\because R_{e}=1.2(0)^{5}, C=.745$

$$
d_{1}=\left[\frac{21}{(236)(.245)\left[\frac{3}{61.63}\right]^{1 / 2}}\right]^{1 / 2}=.74^{\prime \prime} \text { Close EnOUGH! }
$$

A

USE AN ORIFICE OF INTERNAL DIAMETER =3/4"

BD-6002-142 (12/96) 


\section{"SWAGELOK"}

Tube fitters Manual 1993

\section{APPENDIX (SECTION A)}

\section{FLOW \& PRESSURE CHARTS \& CONVERSIONS}

- Flow \& Pressure Charts

- Heads and Equivalent Pressure Conversions

- Pressure Conversions

- Flow Rate Conversions

\section{DETERMINING INSIDE DIAMETER OF TUBING}

The I.D. of tubing is set by flow requirements, permissible pressure drop and maximum allowable velocity. To aid in selecting the proper I.D. of tubing for liquid flow, Charts 1 through 10 are provided on the following pages. Charts 11 through 20 are provided for sizing tubing for gas flow.

These charts give pressure drop for 100 feet of tubing for both water and air flow. By using the formula provided, it is also possible to obtain the pressure drop of fluids other than water and gas.

To allow for pressure drops in bends and fittings, the equivalent lengths in Table $A$ can be used when obtaining equivalent length of tubing for pressure drop calculations. To obtain equivalent length of tubing, total all straight lengths and then add lengths for each bend, elbow or tee from Table A.

\section{EQUIVALENT FEET OF STRAIGHT TUBE}

\begin{tabular}{|c|c|c|c|c|c|}
\hline $\begin{array}{c}\text { Tubing } \\
\mathbf{0 . D .} \\
\text { (In.) }\end{array}$ & $\begin{array}{c}90^{\circ} \\
\text { Elbow } \\
\text { (ft.) }\end{array}$ & $\begin{array}{c}90^{\circ} \\
\text { Bend } \\
\text { (ft.) }\end{array}$ & $\begin{array}{c}180^{\circ} \\
\text { Bend } \\
\text { (ft.) }\end{array}$ & $\begin{array}{c}45^{\circ} \\
\text { Bend } \\
\text { (ft.) }\end{array}$ & $\begin{array}{c}\text { Tee } \\
\text { Branch } \\
\text { (ft.) }\end{array}$ \\
\hline $1 / 4$ & 1 & $1 / 2$ & 1 & $1 / 2$ & 1 \\
\hline $3 / 8$ & $1-1 / 2$ & $1 / 2$ & 1 & $1 / 2$ & $1-1 / 2$ \\
\hline $1 / 2$ & 2 & $1 / 2$ & 1 & $1 / 2$ & 2 \\
\hline $5 / 8$ & $2-1 / 2$ & 1 & 2 & $1 / 2$ & $2-1 / 2$ \\
\hline $3 / 4$ & 3 & 1 & 2 & $1 / 2$ & 3 \\
\hline 1 & $4-1 / 2$ & 1 & 2 & $1 / 2$ & $4-1 / 2$ \\
\hline $1-1 / 4$ & 5 & 2 & 4 & 1 & 5 \\
\hline $1-1 / 2$ & 6 & 2 & 4 & 1 & 6 \\
\hline 2 & 9 & 2 & 4 & 1 & 9 \\
\hline
\end{tabular}

Table A

CHART $33 / 8$ inch O.D. Tubing

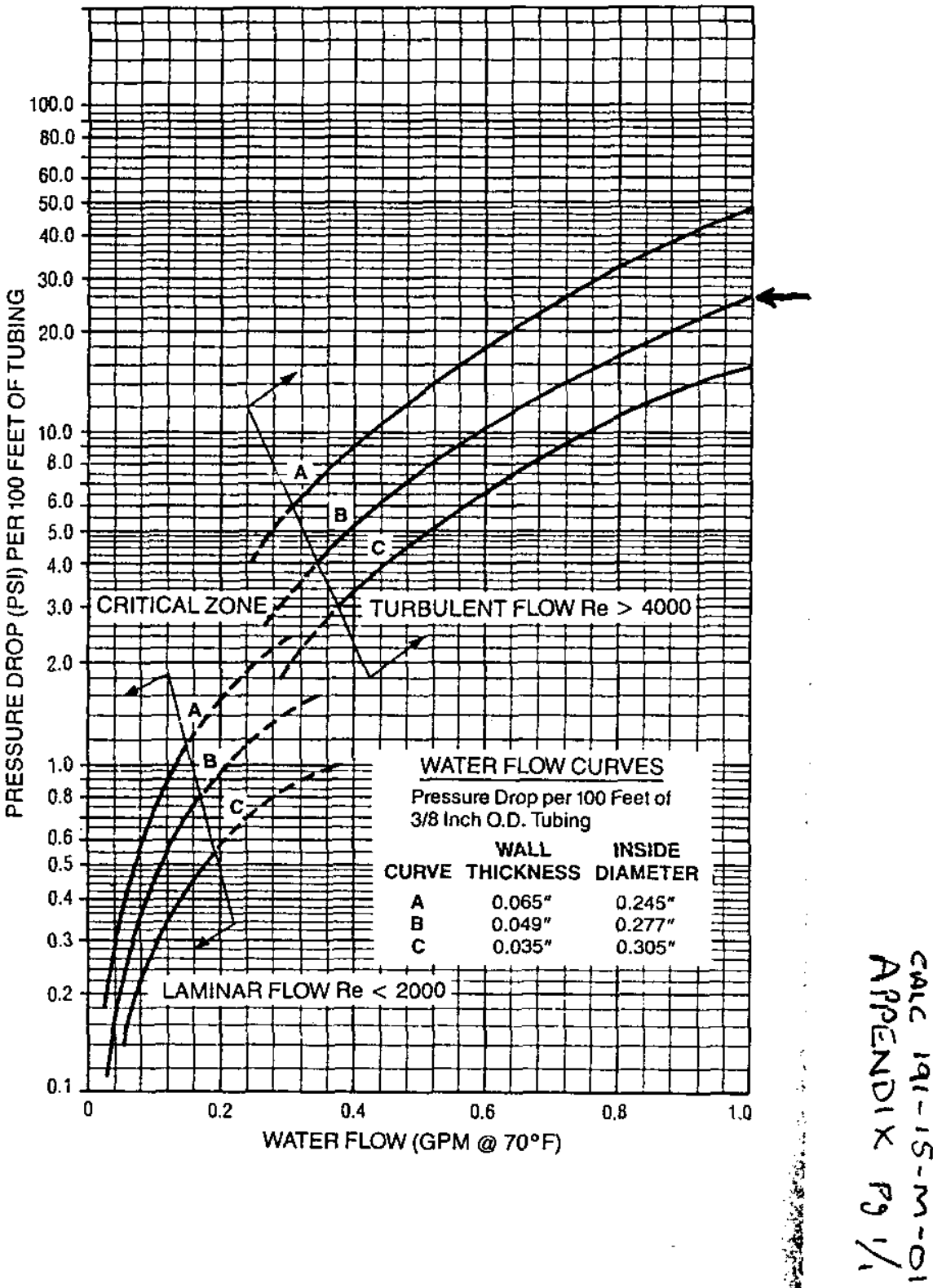




\section{CORRESPONDENCE DISTRIBUTION COVERSHEET}

Author

Scott D. Ellingson 373-1151

Addressee

Correspondence No.

Subject: ETF Evaporator Skid Orifice Sizing Calculations

\section{DISTRIBUTION}

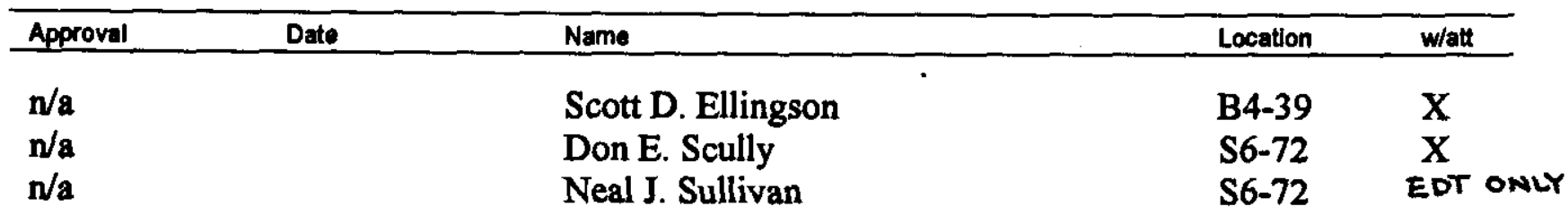

